\title{
戦後イタリア都市計画による農業地域とその景観の保存活用に関する通時的研究 DIACHRONIC STUDY OF CONSERVATION AND UTILIZATION OF HISTORICAL LANDSCAPE IN AGRICULTURAL REGIONS WITH ITALIAN TERRITORIAL PLANNING AFTER SECOND WORLD WAR
}

\author{
植田曉*
}

Satoshi UEDA

\begin{abstract}
In Italy, the conservation and utilization of historical cities, landscapes and regions are conceptual values that have always coexisted with modern urban planning. With post-World War II reconstruction, urban planners began studying ways to conserve historical landscapes in agricultural regions. They established planning methods from a botanic perspective and human geography perspective. Since 2006, in their cultural landscape management plan, urban planners have connected the conservation of physical historical landscape to the recuperate of social and economic foundations of a region. In such way, they have completed a scheme that draws on the history of a region.
\end{abstract}

Keywords:Tessuto, Territorio storico, Paesaggio storico, Regional resource, Cultural landscape, Management plan テッスート，テリトーリオ・ストリコ，パエサッジョ・ストリコ，地域資源，文化的景観，保存管理計画

\section{1. はじめに}

イタリアの歴史的地域資源の保存と活用は、建築や建造物、都市 や景観の真正性を尊重した物理的な成果のみではない。歴史のなか で培われた地域のコミュニティや経済活動に付加価值を与え、持続 可能な社会として再生することも目的とされている。とくに近年は 「(歴史的）景観=パエサッジョ（・ストリコ）」の保存と「(歴史的) 地域=テリトーリオ (・ストリコ)」の活用の成果がめざましい。 故郷をさすパエーゼから派生した単語であるパエサッジョに「先人 の営みが生み出した造形」という意味、領土をさすテリトーリオに「都 市と周囲の農業地域や自然の有機的な結びつきからなる自立した定 住環境」という意味が込められてきたことは、伝統的とすらいえる。

\section{1 研究の背景、我が国における既往研究、本研究の目的}

我が国とイタリアの農業地域ではとくに、(1)近代化の過程におけ るテリトーリオという意識の喪失、(2)第 2 次世界大戦後のパエサッ ジョの著しい変容、以上の 2 点課題が共通していた。後者の原因は 農業改革と働き手の流出による人口減少、経営規模の拡大、耕地の 拡張、機械化と多岐にわたった。イタリアでは審美的な景観の保護 を目的とした法が 1922 年に制定されたものの、制御しうるパエサッ ジョの範囲は狭く、テリトーリオは明確に定義されなかった。大戦 直後には、パエサッジョは用途ごとに細分化された土地利用の表徵、 テリトーリオは地域計画の範囲としてのみ理解される傾向にあり、 歴史的価值の喪失が危惧された。パエサッジョ・ストリコの保存と テリトーリオ・ストリコの活用にむけた検討は、都市計画界におい て戦後復興の一環として着手され、1980 年代後半には、その将来的 な価值が再評価された。この延長上に人文地理学者が 20 世紀初頭に
提唱し、ユネスコの世界文化遺産の分野のひとつとなった文化的景 観の保存管理計画と都市・地域計画を結びつける取り組みもある。

我が国には市壁が囲む「歴史的市街地＝チェントロ・ストリコ」の保 存活用、都市計画、文化財や景観財の保護注 1 、環境価值の高い地域 を保護する制度注 2 、歴史と観光を結びつけた地域経営手法注 3 にかん する、イタリア都市研究の豊かな蓄積がある。一方、農業地域のパ エサッジョの保存とテリトーリオの活用注4 にかんする報告は少ない。

拙稿は地域づくりに結実した農業地域の保存活用の取り組みを、 都市計画の理念と計画手法の発展の系譜として俯瞰することを目的 とする。とくに(1)パエサッジョの定義が対象領域を広げ、複合化し、 テリトーリオと一致するに至った過程、(2)定住環境の有機的結び つきや全体像を、詳細な分析を基に横断的なスケールから定義する テッスートというイタリアで独自の発展を遂げた概念に着目する。

\section{2 研究の方法}

執筆にあたり、戦後に刊行された都市・地域計画の研究書、計画 書、行政資料の読解をもとに考察した。そこに引用された美学、地 理学、植物学の文献、古地図も参照した。具体的記述を旨とし、啓 発的先駆的と考えうる事例を取り上げ、専門家にもヒアリングした。

時間認識として、(1)目標と展望を設定し、先駆的実践を伴う思 想醸成期にあたる戦後から 60 年代初頭まで、(2)パエサッジョとテリ トーリオを定義し、農業地域のパエサッジョ・ストリコの分析手法 を構造的に確立した 1960 年代から 80 年代初頭まで、(3)農業地域の パエサッジョ・ストリコの保存が社会的経済的政策的に可能とな り、実践された 1990 年代初頭から今日まで、以上の 3 区分とした。 空間認識として 2.1 に述べる、テッスートという視点を軸とした。 


\section{2. 第 1 期・歴史的地域資源の保存活用に向けた基盤づくり}

都市計画法が 1942 年に制定されたイタリアの特徵として、(1)ゾー ニングを手法として、我が国の 5 地域にあたる国土全域を制御する 近代都市計画を実践すること、(2)その担い手が率先してチェントロ・ ストリコの保存活用を推進したこと、以上の 2 点がこれまで紹介さ れてきた ${ }^{\text {注。 }}$ 。リオ・ゾッカやルイジ・ピチナートら都市計画家に よる、ルネサンス期よりも前に完成した中世の市街地の調査は先見 的であり、とくにピチナートは今日でいう「都市形態=モルフォロ ジア・ウルバーナ」を 7 つに類型化し、都市調查の礎とした。

チェントロ・ストリコをはじめとした歴史的地域資源の保存活用 と近代都市計画の両立は、都市計画法の施行直後から全国都市計画 協会 (以下 INU) において検討された。INUに設置された作業部会は「復 興にむけた都市計画と建造物の展望注6」を1944 年から翌年にかけて発 表した。(1)農業、(2)産業と商業、(3)観光と環境、以上を復興の 3 つ の枠組みとして提唱しつつ、チェントロ・ストリコの保存活用、パ エサッジョの眺望、環境、以上の保護すべき 3 要素も明文化した。

\section{1 テッスートという概念の導入と都市計画界への普及}

テッスートという定住環境を俯瞰する概念は 1950 年に、都市を対 象にガストン・バルデとサヴェリオ・ムラトーリが「都市組織=テッ スート・ウルバーノ」を提唱したことにより、注目された注７両者 とも不動産登記資料（カタスト）の活用を前提とした。バルデによる 住民の社会的属性と建造物の利用状況を組み合わせた「都市のかた ち=フォルマ・ウルバーナ」は、のちにカルロ・アイモニーノとア ルド・ロッシが起源を辿って体系化した都市論の、形態学的視点に 含まれる。ムラトーリは 1950 年からヴェネツィア市、次いでローマ 市のチェントロ・ストリコを「建築類型＝ティポロジア・エディリ ッィア」の視点から分析した。機能を指標とするのではなく、歴史 的に形成された空間の特質を類型化の根拠とした。市街地を有機的 かつ不可分な組織体として論ずるうえで、個々の建造物を「テッスー 卜を構成する建造物＝テッスート・エディリッィオ」、市街地を「テッ スート・ウルバーノ」と定義した。都市形態学と建築類型学、双方 の手法は、市街地を定性的に分析する基礎となり、テッスートを冠 した用語は都市計画、都市史、建築意匠の各分野で急速に普及した。 都市計画界の例としては、1957 年に開催された INU の第 6 回全国大会 「都市と田園のパエサッジョの保存と有効利用」の採択文、ジョヴァ ンニ・アステンゴを中心に 1960 年に設立された全国歴史芸術都市 保存協会（ANCSA）の設立大会の採択文を挙げることができる。

\section{2 啓発的テリトーリオ研究とパエサッジョという課題の発見}

主たる社会的経済的営みを農業とする中山間地域のテリトーリオ 調查が 1955 年には各地で開始された。国が農業の近代化を標榜して 改革を進めるなか、中山間地域の過疎化は急激に進み、荒廃の末に 放棄されか福ない危機に瀕していた。地場の産業構造を再生する持 続可能な手段を模索する過程で、小規模なチェントロ・ストリコや 農業地域のパエサッジョが保存活用の対象として着目された。代表 的な研究として、プリニオ・マルコーニによるテヴェレ川中流域、 マリオ・コッパによるウンブリア州、エドアルド・デッティによる リグーリア州とトスカーナ州の調查をあげることができる。マルコ ー二は農業地域のパエサッジョを審美的歴史的視点から記述し、コ ッパ、デッティは歴史的視点から構造的に読みとく展望を示唆した。

テリトーリオの分析と地域再生に向けた提言は、より啓発的内容
を伴った。マルコーニは計画対象として、テヴェレ川の分水嶺を根 拠とした 24 基礎自治体（以下コムーネ）を選定した。コッパはローマ 時代の開拓の範囲、中世のコミュニティの領域、今日の行政界とし てのテリトーリオが、いずれも一致しないことを導いた。デッティ は中世の都市国家のテリトーリオに着目した。縁辺部の農業地域で は戦争中ですら隣国と交流が続き、地域社会が維持されていたとい う史実を計画範囲のモデルとして、広域の地域計画を提唱した。

\section{3 都市計画マスタープランとパエサッジョ・ストリコ}

1954 年に都市計画マスタープランの策定時限を 1961 年までに定め た法が施行された。マスタープランの策定にあたり、多くの都市が 中心課題に据えたのが市街地再生だった。チェントロ・ストリコを 職住近接型の居住環境として再生す心゙く、新市街地を隣接させて造 成し、都市を一体化し、相互の機能を補完する手法は啓発的だった。

チェントロ・ストリコと農業地域のパエサッジョ・ストリコの一 体性に着目した例外的な都市計画マスタープランは、アステンゴに よるアッシジ市の計画（1957 年）と、ジャンカルロ・デ・カルロに よるウルビーノ市の計画 (1964 年)のみだった。アステンゴは計画に 先立ち、(1)行政界としてのテリトーリオは、都市国家アッシジが $12 \sim 13$ 世紀に形成したテリトーリオ・ストリコの $2 / 3$ にすぎないこと、 (2) コムーネ全域のパエサッジョが自然美保護法に基づき守られたこ と、以上 2 点から行政界全域を土地利用規制の対象とした。農業地 域全域の個票や収量を調查をし、農地改良や作付けの変更にたいして、 地区詳細計画に匹敵する要件の農用地利用計画の提出を義務づけた。 とくにチェントロ・ストリコをとりまく農地を手厚く保護した。 デ・カルロは今日の行政界としてのテリトーリオのうち、チェント ロ・ストリコと一体をなし、都市形態の一部として保存すべきパエ サッジョの範囲を選定した。そのうえで地形に応じて景観重要稜線、 眺望点、景観軸や景観視円錐を設定した。新市街地の造成や企業誘 致のため、建造物の容積規制や敷地の外周緑地の設置条件も整えた。

\section{4 本章の考察}

戦後の復興の展望に記された理念は体系化には至らなかったもの の、多角的取り組みにより、明らかに実現の可能性が共有された。

テッスート・ウルバーノという 2.1 に述ベたイタリア独自の概念 は、その抽象性ゆえに、市街地の有機的な全体像を具体的に定義 する立脚点となり、普及した。研究者や計画家にとって、テッスー 卜を定義することは自明となり、そのことが次章以降に述べるよう に、パエサッジョやテリトーリオを定義づけるうえでも貢献した。 この時代にはパエサッジョ・ストリコの保存の重要性は意識され ていたものの、(1)テリトーリオとは別の課題として考えられていた こと、(2)パエサッジョの分析や計画手法を確立する必要性が明らか になったこと、が 2.2 に述べた各事例から指摘できる。これらの事 例は中山間地域を含む零細な農業地域の活性化という課題に効果的 に取り組むために、複数のコムーネの協働やかつての都市国家を連 動させた再生を想定し、広域化する利点に立脚した。この共通した 見解は、テリトーリオ・ストリコの価值の再評価を促したといえる。

パエサッジョを保存する上で、2.3 でとりあげた都市計画マスタ ープランの 2 事例において、アステンゴは都市計画的手法を、デ・ カルロは建築的な手法を採用した。前者の手法がこの後、広く普及 した。とくにアステンゴが農地の土地利用規制と個票調查の両立を 検討したことは、後年に大きな示唆を与えたと考えられる。 
3. 第 2 期 1 農業地域のパエサッジョとテリトーリオの複数の定義 レオナルド・ベネーヴオロは 2.1 でとりあげた第 6 回 INU 全国大 会で、パネリストのひとりとして「環境のなかで多様な要素が共存 した状態」こそパエサッジョの本質と論じた注8。パエサッジョはこの 大会決議で、従来の審美性に加え、原生的自然という環境と、先人 の営みといら歴史から生じた人文的空間としても定義された。後者 には農業地域も含まれた。このときから(1)審美的、(2)環境的、(3)歴 史的側面という複合化す心゙き $3 つ の$ 視点が確立されたと理解できる。

他分野でも同じ時期にパエサッジョの定義を巡り、議論された。

大衆の啓発面では、地理学者アルド・セスティーニが、ついで都 市・地域計画の分野でグイド・フェッラーラが、専門家による写真 解説という表現をとおして、上記の 3 つの視点からパエサッジョを 俯瞰した。次節ではこれらの視点を概観する。

\section{1 戦後に確立されたパエサッジョ・ストリコの3つの定義}

\subsection{1 審美的視点から定義されたパエサッジョ・ストリコ}

ルネサンス以降、田園生活や領地の財の豊かさが絵画の背景とし て描かれるようになり、のちに主題となり、美術評論を経て、パエ サッジョそのものの審美的価值が確立された。哲学者にして歴史家 だったベネデット・クローチェが、1902 年に近代思想のなかでパエサッ ジョを「美」と定義して以来、その価值観が今日まで受け継がれた。 パエサッジョの保護を定めた制度的概念は 18 世紀にさかのぼった。 20 世紀に入り、文筆家にして行政官だったルイジ・パルパリオロが、 1904 年に農業にかんする総合的な法体系を、1913 年にパエサッジョ という文言を含む芸術全般を保護する法体系を構想した。公教育大 臣に就任したクローチェは 1920 年法案第 204 号を上院に諮った際の 演説で、審美的景観のある側面として「農場の喜び」に言及した。 同法案は景勝の保護を目的とした 1922 年法第 778 号「自然美と歴史的 価值のある不動産の保護法」(通称クローチェ法)として公布された。 引き続き施行令が検討されたが、詳細な保護規定を求める国民運動 もおこった。パオラ・ファリーニは 1931 年 2 月にイタリア観光協会 が主催した法改正を求める会議を重視する。この会議でパルパリオ ロはパエサッジョの保存には都市計画による制御が不可欠と論じた。 これらの取り組みは景観計画の策定を義務づけた 1939 年法第 1497 号（自然美保護法）に結実し、その施行令も翌年に成立した。

戦後になり、哲学者ロザリオ・アッスントはクローチェの研究を 継承しつつ、時間の概念を導入した。パエサッジョを時の流れが凝 縮され、記憶を投影しうる対象と定義した。農業地域のパエサッジ ヨは常に移ろい、季節ごとに繰り返すことに意義があると指摘した。

\section{1 .2 環境的視点から定義されたパエサッジョ・ストリコ}

植物学者ヴァレリオ・ジャコミーニは従来のパエサッジョの定義 に、生態学という自然科学の側面を重礼て啓発した。パエサッジョ を生物圈（バイオスフィア）注９関係づけ、環境面から論じた。 その成果は、(1)農業地域のパエサッジョ・ストリコをバイオスフィ アの重要な要素として位置づけたこと、(2)生物圈の保護を現実化す るべく取り組んだこと、以上の 2 点である。

ジャコミーニは 2 次的自然に、原生的自然を保護する緩衝地域と しての役割りを期待した。なかでも自然と調和した伝統的な農業地 域を最重要視し、そのパエサッジョの保存を訴えた。近代農業が環 境保護に寄与し得ないことを危惧し、その原因を専門家の職域の狭 さに起因するとした。異分野の研究者や専門家が協㗢する場の必要
性を唱え、その実践の場として 1950 年には 10 名の会員、自身も会長 をつとめた「庭園と景観の設計者協会」を設立した。1966 年には、 原生的自然を構成する動物、植物、鉱物の関係をテッスート、そ の表徵をパエサッジョ、複数のパエサッジョが連動した状態をテ リトーリオ、自然保護公園として設立すべき規模を州の広さ以上と論 じた。この論を景観生態学と呼んでいたと、ヴァレリオ・ロマーノ は指摘する。ただしジャコミーニによるテッスートは、原初的自然 の有機的な仕組み、パエサッジョは自然美を指し、これら 2 つ語 彙が、拙稿でとりあげる他の語彙とは相容れない点に留意したい。

\subsection{3 歴史的視点から定義されたパエサッジョ・ストリコ}

地理学者ブルーノ・ニーチェは、1950 年に INU の機関誌「ウルバ ニスティカ」に寄稿した論文「地理学と都市計画」において、地理学 的視点を都市・地域計画に導入する意義を唱えた。この時期に、イ タリアの地理学が刷新された。レナート・ビアズッティは科学的根 拠に基づくパエサッジョを論じ、セスティーニはオットー・シュ リューターが提唱した文化的景観を啓発した。

農業地域のパエサッジョ・ストリコにかんする研究は、1950 年代 の後半から急速に進んだ。農業史家エミリオ・セレーニ、人文地理 学者であるルーチョ・ガンビやエウジェニオ・トゥッリが新たな視 点から論じた。セレーニとガンビは情報を共有し、協働もしていた。

セレーニによる成果は、(1)農業者の立場から農業改革の課題を明 らかにし、とくに小規模農業者が新たな弱者層になりつつあると指 摘したこと、(2)イタリアの農業史を俯瞰したこと、(3)ルネサンス初 期にはすでに農業地域の景観計画にあたるものがあったと論じたこ と、以上の 3 点である。とくに(3)を根拠に環境と歴史を守り、農業 者と農産物の実情に即した景観計画の普及を図る必要性を説いた。

ガンビは歴史的視点を人文地理学の本質と論じ、パエサッジョ・ ストリコを分析的に記述した。安定した地域社会のメカニズムが歴 史的に重層したさまを文化的景観とした。戦後の農業地域を、農家 の経営規模や主たる作付けを指標として類型化し、地域ごとに残さ れた多様性を評価した。イタリア半島における5000 年の定住の歴史 を、環境との関係から 5 段階に分類し、伝統的な混作農法や生け垣で 囲まれた農地（カンポ・キウゾ）全てを等しく評価する視座を築いた。

トゥッリは環境的視点、歴史的視点、双方を統合する立場からパ エサッジョを論じた。地理学者カール・サウアーが提唱した文化的 景観にも言及し、農業こそ、最も雄弁に文明を語るものとした。都 市・地域計画学の分野が論ずるパエサッジョが(1)狭い土地利用をさ 寸にすぎないこと、(2)同分野で論じるテリトーリオこそ、他分野で 論ずるパエサッジョにあたると指摘し、より広い視点をもつことを 都市計画界に促した。テリトーリオとパエサッジョは同義であると 述べ、テッスートを人類の歴史の総体的な足跡の表徵と定義した。

\section{2 都市・地域計画におけるパエサッジョとテリトーリオの定義}

前節でとりあげたセレーニ、ガンビ、トゥッリは社会、経済、技 術を裏付けに、農業地域のパエサッジョ・ストリコを詳述しただけ ではなかった。三者とも、農地の市街化や耕作放棄地の急増を幅広 い資料から把握し、農業地域のパエサッジョ・ストリコの第状を指 摘した。ガンビ、トゥッリは都市計画界の対応の遅れも指摘した。

本節では、1960 年代後半から 70 年代の前半にかけて都市計画界 で共有された、ヴィットリア・カルツォラーリによるパエサッジョ、 ムラトーリによるテリトーリオの定義を検証する。 


\section{2.1 カルツォラーリによるパエサッジョの定義}

カルツォラーリは「建築・都市計画事典」の編纂において、3.1 で

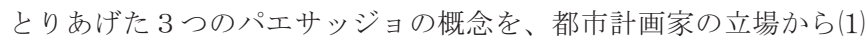
文学、生物学、地理学、都市・地域計画学からのアプローチ、(2)クロー チェやアッスントに代表される審美的アプローチ、以上の 2 つ分 類した。その前提にたち、パエサッジョを歴史的な人工物や自然物 の組み合わせからなる体系（システム）として捉えることを提唱し た。1973 年には国際会議「パエサッジョの構成」で、パエサッジョ を「テリトーリオのエコロジカルな側面と歴史的社会的経済的側面 がひとつの体系となり、立ち現れたもの」と定義し、つねに「ダイ ナミックな進化」を伴うと述べた。カルツオラーリはまた、庭園の 概念が時代を追うにつれて多様化、広域化した点に着目した。パエ サッジョを庭園史の延長として解釈し、可能な限り広い範囲を一体 として定義し、保存活用寸ることを提唱した。その計画技術を絵画 史上の用語である「景観形成法＝パエジスティカ」と呼び、緑地や 自然を保存し、利活用寸るための計画とその技術全般と定義した。

\section{2.2 ムラトーリによるテリトーリオの定義}

ムラトーリは 2.1 でとりあげたテッスート・ウルバーノの形成史 の研究手法を発展させ、1967 年に「テリトーリオのテッスート =テ ッスート・テリトリアーレ」という概念を提唱した。テリトーリオ を、原生的自然に刻まれた人類の足跡として認めうる最も広い範囲 と定義した。人類の精神が 4 つの側面を有するというクローチェの 精神哲学を再定義し、その発展を 4 段階に分けた。発展の節目ごと に、文明に変化が生じ、テリトーリオの活用も変容したと論じた ${ }^{2}$ 。 テリトーリオの活用の 4 段階を、(1)原始時代にあたる森林活用の段 階、(2)古代エジプト第 1 中間期以前、シュメール文明などの農林業 による土地利用の段階、(3)エジプト中王国期以降、バビロニア王朝 などの貨幣経済社会の形成途上の段階、(4)ギリシア文明以降の 4 つ の価值観 ${ }^{i} 11$ を伴い、安定的経済システム、キリス卜教、大土地所有、国 家体制という 4 つ地圻有形式が共存した、今日に至る時代とした。

4 つの時代に共通する空間特性を、道、テッスート、ノード、縁 辺部から記述できるとし、テリトーリオの空間の質を表すのは空間
構造ではなく、面的に広がるテッスートであり、その範囲を経済活 動のために利用された土地、宗教的に意識された土地全域と定義した。

ムラトーリはテッスート・テリトリアーレを(1)分水嶺と河川流域、 (2)国土、(3)大陸という、社会的属性に応じた複数のスケールから設 定した。具体的な事例研究も試みた。地形を山、斜面地、谷、平野 という 4 つに類型化した。先に述べた 4 つの空間の特性から分析 し、テッスートの最小単位を、地形ごとの類型にそった農場とした。

その没後はパオロ・マレット、ジャンフランコ・カニッジャら、 ムラトーリ学派が研究を引き継いた。マレットは、(1)テッスート・ エディリッィオ、(2)テッスート・ウルバーノ、(3)テッスート・テリ トリアーレ、以上の 3 つのヒラルキーからなる明快なテッスート 論を提示した。農場のテッスートを類型化するうえで、家屋を農場 全体の土地利用と関係づけてこそ、空間特性を把握できるとした。 カニッジャはムラトーリの論考を体系化し、人類学的空間と呼び、 普及に貢献した。実践面でもロンバルディア州コモ市周辺に分布す る、ローマ起源の市街地と農業地域の地割り、同州の山裾に広がる 丘陵地帯を対象に、「分水嶺と河川流域のスケール」における谷地 形と丘地形、そこに分布する小河川と道のネットワークを研究した。

ムラトーリ学派はきわめてまれにパエサッジョに言及したが、そ の関心はつねにテリトーリオを読むことにあった。

\section{2.3 本節の考察}

カルツオラーリの成果は、1973 年の国際会議においてパエサッジ ヨを、(1)行政界を示すテリトーリオの表徴として定義したこと、 (2)歴史と自然からなるシステムとして定義したこと、以上の 2 点 だった。ムラトーリの成果は、(1)文明の発展段階と定住環境の成り 立ちが対応寸ること、(2)市街地、農業地域、原生的自然の有機的な 関係をテッスートとして論じうること、(3)テッスート・テリトリアー レは数段階のスケールから認識しうること、以上の 3 点だった。

トゥッリの定義も含め、パエサッジョとテリトーリオの複数の定 義は構造的に整理され、両者の空間的領域は一致をみた。テリトー リオの歴史的な意味がよみがえり、テッスートはその有機的な全体 像をしめ寸概念として共有されるようになったと考えられる。

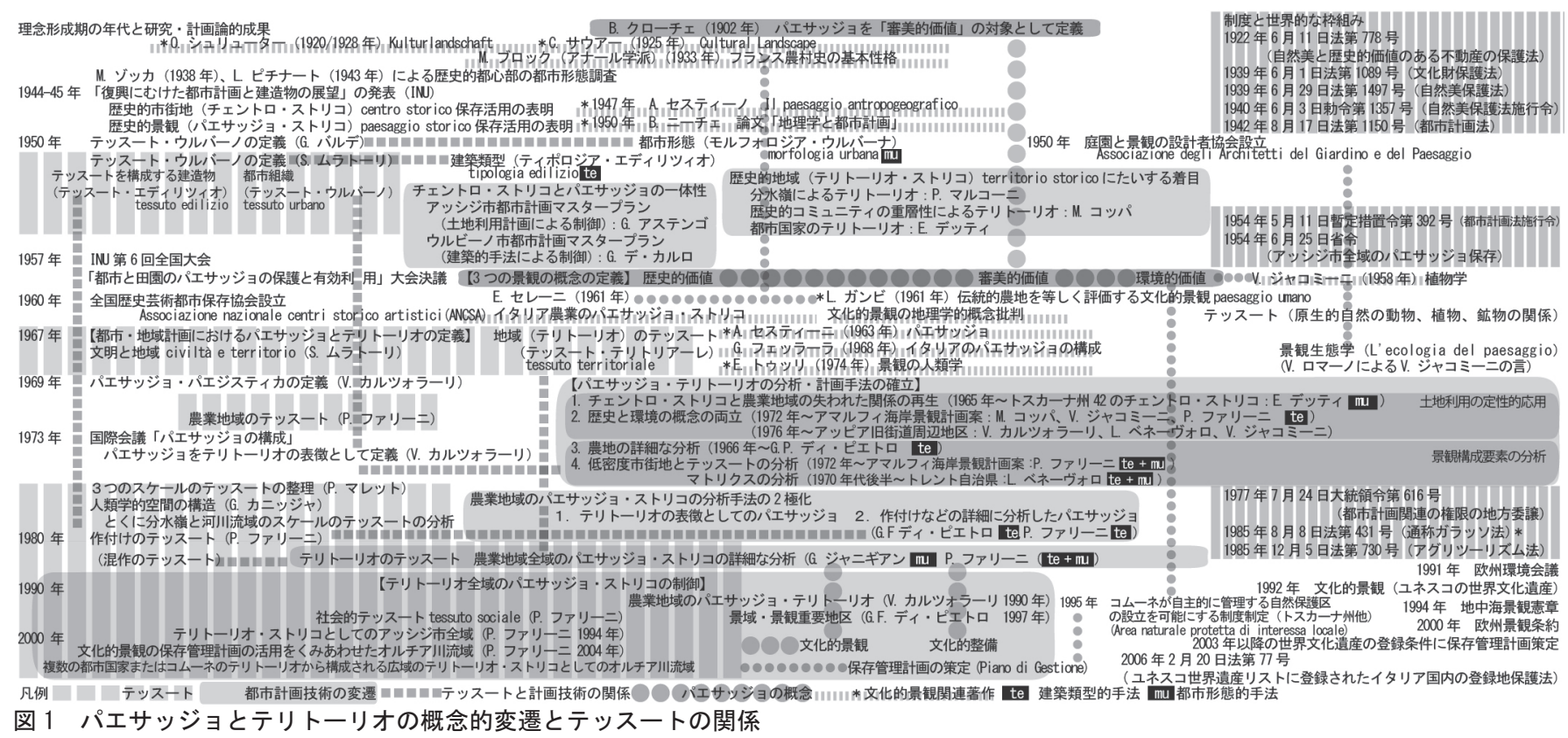


4. 第 2 期 2 ・ パエサッジョ、テリトーリオの分析 ·計画手法の確立 パエサッジョとテリトーリオの定義づけと並行し、その保存活用 に向けて近代都市計画の手法、チェントロ・ストリコの分析手法の 応用が各地で模索された (図 1) 注12。多岐にわたる課題は、(1)チェントロ・ ストリコと農業地域の失われた関係の再生、(2)環境と歴史の概念の 両立、(3)中山間地域における歴史的な農地の評価、(4)低密度市街地 とそのテリトーリオの評価、以上の 4 点に整理することができる。

これらの課題に 1970 年代初頭から約 10 年をかけて取り組んだ結果、 パエサッジョを土地利用、ついで景観構成要素から分析する手法が 確立された。 4.1 で土地利用の評価基準を整理した 1970 年代中期まで、 4.2 で景観構成要素の分析の初期段階である 1970 年代末まで、 4.4 で 土地利用と要素分析を両立し、テリトーリオ全域を分析する手法を 確立した 1980 年代初頭まで、以上の代表的な事例の成果を検証する。

\section{1 土地利用の定性的応用という視点の確立}

上記(1)歴史的関係性の再生、(2)環境と歴史の両立、という課題に 共通して必要とされたのは、パエサッジョやテリトーリオの全体像 を定性的に把握することだった。これらの課題にたいして近代都市 計画の手法である土地利用を応用する分析方法が検討された。

\subsection{1 チェントロ・ストリコと農業地域を結びつける土地利用}

本項ではデッティがジャン・フランコ・ディ・ピエトロ、ジョヴァ ンニ・ファネッリとともに 1965 年に開始した研究をとりあげる。

デッティはトスカーナ州の農業地域に点在する 42 の小規模なチェ ントロ・ストリコとその周辺を対象とした個票調査から、土地利用 の変容の傾向を指摘した。当時は 1.1 (1)に記したテリトーリオとい う意識の袁失を、2.3でとりあげた市街地再生手法がさらに、チェン トロ・ストリコと農業地域の関係を損なうかたちに助長していた。 具体的にはa) 住み手にとって認識しづらくなった歴史的環境の一体性、 b) 市街地の周りの農地にたい寸る新しい建造物のスプロール、以上 の 2 つ新たな課題が生じていた。アステンゴとデ・カルロが回避 を試みたこれらの課題が全国に共通することを、デッティが初めて 立証した。デッティはチェントロ・ストリコと農業地域の双方で、 19 世紀後半と 1950 ～ 68 年の個票を同じ方法によって比較調查する方 針を立て、ディ・ピエトロは市壁外を、最新の地籍境界が入った土 地利用現況図として描き、変容の実態を詳述した。本調查をとおし てデッティは、チェントロ・ストリコとテリトーリオの一体的保存 活用を訴え、2.2で言及した都市国家のテリトーリオの縁辺部を、歴 史的な社会構造と経済、地形から判断しうると論じた。さらに土地 利用計画を基本とした都市計画手法による地域の制御を示唆した。

\section{1.2 パエサッジョの環境と歴史の概念を両立させうる土地利用}

本項ではマリオ・コッパが 1972 年に策定したアマルフィ海岸景観 計画案と、環境保護団体イタリア・ノストラが市民運動として 1976 年に提案し、アッピア旧街道州立公園に発展した計画をとりあげる。

ジャコミーニとファリーニが参加したアマルフィ海岸景観計画案 は、景観保護計画と観光発展計画をひとつの総合計画に仕立て、従 来の景観計画よりも広大なテリトーリオを対象とした初の試みだっ た。複雑な地形にたいして、ジャコミーニは視認性が高い尾根筋に 分布する森林の面的保護を考案し、ファリーニは海岸沿いと内陸の 谷部に分布する定住環境を、用途に応じて細かく制御する手法を考 案した。コッパはこれらの案を組み合わせ、景観計画を用途が重複 せず、白地もないゾーニングに基づく土地利用計画として提案した。
ローマ市のアッピア旧街道周辺地区は既存の都市計画マスタープ ランや景観計画により線引きのみがされていた。同団体はカルツォ ラーリを中心に、ベネーヴオロが都市・地域計画学面を、ジャコミー ニが植物学面を補佐する体制を整えた。都市緑地と都市公園の役割 も兼䄈た考古学公園計画を、詳細な土地利用計画を基本として提案 した。植物学者らは牧草地の植生が自然環境保全に有益と指摘した ${ }^{13}$ 。

カルツォラーリは景観断面を作成し、その類型と土地利用を組み 合わせた。アッピア旧街道周辺の自然と歴史を有効に保存するため、 公園の計画範囲そのものも再検討した。その指標として水系と考古 学遺跡に、とくに着目した。景観断面を利用した水系の分析により、 生物圈のつながりを明らかにし、地上では離れて立地する複数の場 所を関連づけた。ベネーヴオロによるチェントロ・ストリコの市壁 の内外に分布する考古学遺跡にかんする既往研究は、チェントロ・ ストリコとアッピア旧街道周辺地区を結びつけた。土地利用指定に より、広大な歴史的空間の連続性を生み出す可能性をも示唆した。

\section{2 景観構成要素の分析という視点の確立}

本章冒頭の(3)歴史的な農地の詳細な分析、(4)低密度な定住環境の 分析、という課題に共通して必要とされたのは、非建造物により景 観構成要素を位置付け、適正な分析のスケールを把握することだっ た。これらの課題にたいしてチェントロ・ストリコの分析から発展、 普及した建築類型学、都市形態学を応用する分析方法が検討された。

\subsection{1 中山間地域における農地のパエサッジョの詳細な分析}

人文地理学の分野では 3.1 .3 でとりあげた歴史的農業地域の保護 を早くから啓発してきた一方、空間的な分析手法を必要としていた。

ディ・ピエトロはファネッリとともに 1966 年からトスカーナ州ア レッツォ県ティベリーナ地域の、文化財指定すべき地域資源を調査 した。農業地域のパエサッジョ・ストリコを文化的景観と捉え、従 来は調查の対象とされなかった(1)小規模な建造物群、農業地域や森 林に点在する建造物の類型化、(2)ガンビの定義に基づいた農地の類 型の、航空写真と状況写真を用いた視覚的資料化、以上の 2 点に取 り組んだ。ディ・ピエトロはこの後、テリトーリオの形態学的研究 から、パエサッジョの景観構成要素の類型学的分析に研究を広げた。

\section{2.2 低密度市街地とテッスート・テリトリアーレを分析する試み}

ファリーニは 4.1 .2 でとりあげたアマルフィ海岸景観計画案で地 形と定住環境の関係を、市街地、道路、農地の立地という分析項目 から形態学的に分析した。市街地の類型化の対象にチェントロ・ス トリコのみならず、密度の低い定住環境も加えた。類型化の対象を、 斜面地に造成された菜園や段畑といった農地や庭園の形状と作付け、 街道や生活道、農道に広げ、農業地域のテッスートを明らかにした。 市街地から離れて単独で立地する小規模な宗教建築も、地形と関連 付けることで類型化しうると論じた。形態学的視点と類型学的視点 を組み合わせた分析方法として、初期の取り組みだった。

ベネーヴオロは都市計画顧問をつとめたトレント自治県で、1970 年代末から歴史的定住環境の再生に向けた調查をした。テリトー リオの広範を農地、植林地、関連寸る第二次産業のために担保され た空地が占めていた。県全域に点在する市街地のテッスートのみを 捉えたとしても、歴史的資源の一部にすぎないと指摘した。地域の 状況を「テリトーリオを形成する歴史的マトリクス」とよび、建築 類型学的視点、都市形態学的視点を複合した分析方法を考案した。 (1)類型化の対象となる建築を広げたこと、(2)主たる施設や付帯施設 
の配置とその外構、さまざまな規模の道路や水路を分析項目とし、 空地の特性を浮き彫りにしたこと、以上の 2 つの結果を重祆合わ せ、市街地の全体像と、その周辺のテリトーリオの関係を形態学的 に分析した。とくに単独で立地する第 2 次産業用の施設は、建造物 が同じ類型に属したとしても、業種によって屋外の利用方法、道の 分布や市街地との関係に相違があった。そこで周囲のマトリクスの 分析結果を、建造物の類型の評価項目に加える手法を考案した。

\section{3. 土地利用と景観構成要素の分析にかんする 3 つ考察}

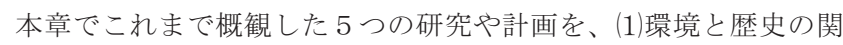
係、(2)建築類型と都市形態の関係、(3)計画学のうえで共有されたパ エサッジョの 2 つのスケール、以上の 3 つの視点から考察する。

(1)環境と歴史という視点は、第 6 回 INU 大会以降の課題だった。 アマルフィ海岸景観計画案では相互の視点が干渉しないようにし、 アッピア旧街道の公園計画案では地表の土地利用と、地中の水系を 2 層と考え、両者が全域的に補完しあうことを立証した。こののち、 環境と歴史という課題は、その優位性をめぐり議論されたとしても、 a) 計画策定の上で両立す心゙き課題、b）歴史評価は戦後の復興の展 望に基づく必須課題、以上の $2 つ の$ 視座が整理された。b はイタリ ア都市計画の個性となり、拙稿でもこの点に着目して論を進める ${ }^{\text {i注 }} 14$

(2)デッティはトスカーナの調查において、異なる時代のカタスト を用いた個票の比較調查により、チェントロ・ストリコと農業地域 双方の土地利用の変容を形態学的に分析しうることを立証した。 ファリーニとベネーヴォロは個票の歴史的比較の結果から、建築類 型学、都市形態学の手法を組み合わせて農業地域を読む新しい視点 を導いた。とくに異なるスケールの類型を、形態分析によって組み合 わせ、テッスートまたはマトリクスを記述しうることを実証した。

(3)パエサッジョを都市計画手法である土地利用と、人文地理学の 分野が論じた景観構成要素という 2 つのスケルから分析しうるこ とを、実践面でも実証しえた。4.1 でとりあげた 3 つの事例は、3.2.3 で定義された、a）パエサッジョの領域とテリトーリオが一致するこ と、b）歴史や環境という定性的評価基準を土地利用によって制御 しうること、以上 2 点を示した。またデッティは、2.3 でとりあげ たアッシジ市の都市計画マスタープラン策定時にアステンゴが考案 した、個票調查に基づく土地利用規制が汎用的であることを実証し た。4.2 でとりあげた 3 つ事例のうち、ディ・ピエトロとファリー 二は、伝統的な農地の詳細な分析をとおして、パエサッジョに優劣 をつける審美性という従来の評価基準を離れ、テリトーリオに分布 する農地すべてが等しく文化的価值を有すると評価しうる道筋を開 いた。ファリーニとベネーヴオロが実践した形態学的分析と類型学的 分析の組み合わせは、詳細な分析による空間認識の可能性を広げた。

\section{4 テリトーリオ・ストリコ全域の詳細なパエサッジョの分析}

農業地域全体の土地利用と景観構成要素の分析を複合化する手法 は、ファリーニ、建築史家ジョルジョ・ジャニギアンが 1970 年代末 のほぼ同時期に確立した。文化的景観を念頭においた点、不動産登 記資料を活用した点で共通していたが、その手法は異なっていた。

\section{4.1 テリトーリオ・ストリコ全域の類型学的分析}

ファリーニはウンブリア州テルニ盆地を事例研究の対象として、 4.2.2 でとりあげたアマルフィ海岸景観計画案の分析手法の精度を力 タストを用いて高め、セレーニが描写した農業地域のパエサッジョ・ ストリコを再生（レクーペロ）する手法を構築した。テリトーリオ
を盆地を囲む丘陵の分水嶺とし、数段階のスケールを設定したうえ、 (1)テリトーリオの地形と土地利用の関係を時代ごとに分析する形態 学的手法、(2)カタストから人為的につくられたものを、建造物に限 らずに分析する類型学的手法、以上の 2 つを組み合わせた。そこか ら、a）テリトーリオ全域を地質、地形、土壌、植生から類型化した こと、b）テリトーリオ全域の土地利用の歴史的変遷を再現して地図 化したこと、c）農場の特徵を地形、土地利用、歴史的背景から 8 通りに分類し、それぞれを全体像、農場の区画形状、建造物、作付 けという4つの観点から分析して類型化したこと（図 2)、以上の $3 つ$ 手法を確立した。c 3.2 .2 でとりあげたマレットが示唆し たテリトーリオの小さな単位である、農場のテッスートを具体的に 分析した結果だった。一方、区画ごとの農地の形状、作付けの規則 性を、例えば「混作農法のテッスート」とよんだ。この視点はムラ トーリによる「テッスートを構成する建造物」に対応すると考えら れる。ファリーニは 4.3. (2)で述べたように、 a と c の分析から導い た類型を形態学的に結びつけ、テリトーリオから建造物や作付けま で、その複合的な特徴を記述する方法を生みだした。テルニ市のチェ ントロ・ストリコとテリトーリオ双方の歴史的変容を共時的に分析 したことも、それまでにはない分析だった。ファリーニはこの成果 を元に実現しうる再生を、文化的整備と名付けた。

\section{4.2 テリトーリオ・ストリコ全域の形態学的分析}

ジャニギアンはヴェネト州アーゾロ市のテリトーリオに残る農 業地域のパエサッジョ・ストリコの保存を目的に、1976 年より調査 を開始した。フランスの歴史学者マルク・ブロックの手法を参照し つつ、同地域の不動産登記資料を精查し、史料の正確さという意味 で大きな発見をした。ヴェネッィア共和国時代の 18 世紀前半に作成 された課税公図には、19 世紀のオーストリア支配下の時代に利用さ れたカタストより、農地の優劣、農家の離れのような建造物の特徴 や用途などの情報が豊富に掲載され、正確かつ詳細に往時の実態を 把握しうることを立証した。そのため、18 世紀の課税公図を基礎資 料としたパエサッジョ・ストリコの調查を提唱した。コムーネ全域 にわたって、カンポ・キウゾや樹木の植えられた農地、混作農法の 作付け、農地の造成など、自然物を利用し、人為的に形成された農 地の姿を形態学的に記録した。ジャニギアンの研究は類型化に向か うことはなく、歴史的な農地を特徴付ける景観構成要素を個別にリ スト化した。これらの要素を、コムーネに分布する価值の高い建造 物や市街地と等価に扱う意義を論じ、テッスート・テリトリアーレ の正確な調查を、その後の地域計画の立脚点とすべきとも述べた。

\section{4.3 本節の考察}

ファリーニは類型学的手法と形態学的手法を複合化し、ジャニギ アンは形態学的手法を採用し、カタストや課税公図といった不動産 登記資料を分析した。両者に共通寸る成果は、(1)テリトーリオ全域 を対象として 4.3 でみちびいた成果を、方法論として整理したこと、 (2)人文地理学で論じられていた文化的景観を、都市・地域計画の手 法で記述する方法を生み出したこと、以上の 2 点にあった。農業地 域のテッスートの類型化を試みたファリーニは、ムラトーリ学派が 提唱したテッスート・テリトリアーレの概念を具体化したといえる。 ジャニギアンは社会的状況が史料の信憑性を左右することを示した。 本章をつうじて考察した土地利用、景観構成要素の分析というふた つの分析手法は、両者の研究により高い精度を伴って体系化された。 
5. 第 3 期・テリトーリオ全域をパエサッジョ・ストリコとした計画 1980 年代に入り、国民の食の安全を求める社会運動、専門家を起 用した啓発的出版物の相次ぐ刊行、制度の制定をとおして、農業地 域のパエサッジョ・ストリコは付加価值の高い生産の現場として多 角的に再評価された ${ }^{2}$ 。 $5 \mathrm{EU}$ の農業政策が環境保全型に転換し、経済 的補助も担保された。復興の展望で提唱された 3 つ枠組みが連動 する社会的経済的条件が整い、パエサッジョ・ストリコを保存し、 テリトーリオ・ストリコを活用した地域づくりが実践可能となった。

\section{1 都市・地域計画によるパエサッジョ・ストリコの制御}

本節では 1990 年代に、啓発的な役割りを担った $2 つ の$ 都市計画マ スタープランと 1 つの県の地域調整計画をとりあげる。いずれもこ れまでにとりあげた調查研究の蓄積を背景に、(1)農業地域のパエサ ッジョ・ストリコを保存活用すること、(2)テリトーリオの一体性を 取り戻すこと、以上の 2 点の実践を見据えた計画として策定された。

\subsection{1 都市計画マスタープランによる制御}

ベルナルド・セッキ、カルツオラーリらが策定し、1990 年に施行 されたシエナ市都市計画マスタープランは、(1)コムーネ全域の市街 地、農業地域、自然を有機的に結びつけること、(2)従来は未指定 だった緑地を環境価值の高い資源として再評価すること、以上の 2 点を基本的課題とした。カルツォラーリはa）地下水脈が形成する緑 のシステム、b) 農業地域の地質と作付けのシステム、c）農業地域 の道と水利のシステム、以上の 3 つを、農業地域の保存活用の指標 として位置づけた。4.1.2 でとりあげた公園計画案で確立した景観 断面の類型化を応用し、 $\mathrm{a}$ と $\mathrm{b}$ の土地利用計画に反映させた。 $\mathrm{a}$ で はチェントロ・ストリコと森林公園や河川公園を結ぶ地下水脈を保 護するため、さまざまな緑地を都市緑地に指定し、連続性を確保し、 b では伝統的な作付けが地形と地質を適切に考慮した結果だったこ とを立証し（図 3)、cでは農業地域全域に点在寸るヴィッラから零 細自作農まで、社会的属性に関わらず、全農家の水と道のネットワー
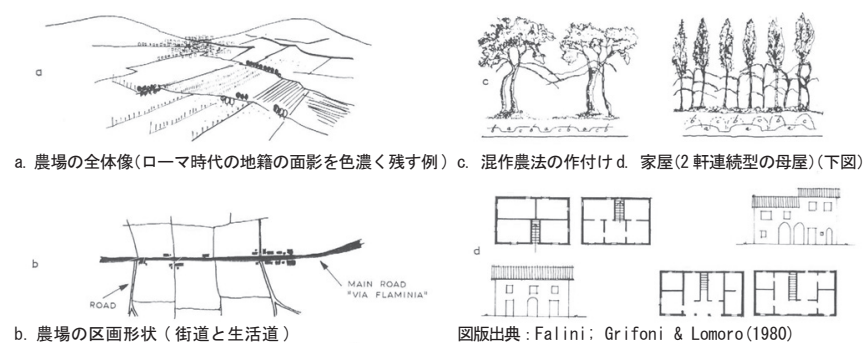

図 2 テルニ盆地に分布する農場の、8つの類型の 1 例（平野部）

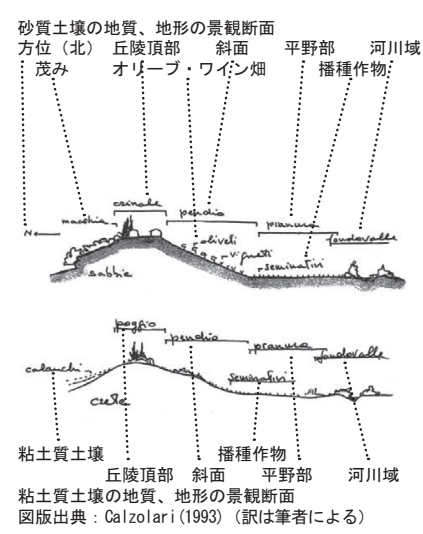

図 3 シエナ市の景観断面

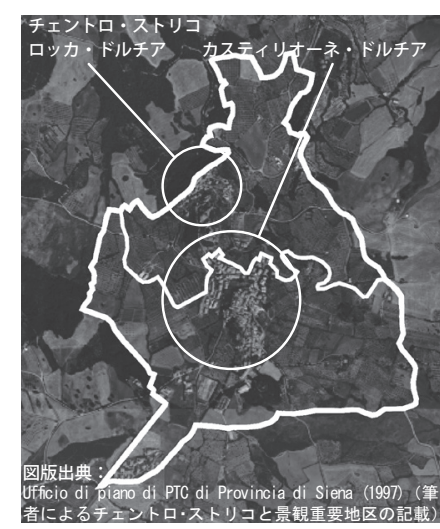

図 4 シエナ県の景観重要地区
クに着目し、保護の対象とした。いずれのシステムもパエサッジョ・ ストリコの保存と環境保全型農業を結びつける視点を有していた。

ファリーニは 1994 年にアッシジ市全域のテリトーリオ・ストリコ を分析した。2.3でとりあげたアステンゴによる都市計画マスタープ ランは、論理的には農業地域を保護する厳密な仕組みを構築してい たものの、現実にはパエサッジョ・ストリコの断片化が進んでいた。 ファリーニはこの研究で(1)コムーネ全域の形態学的側面と類型学的 側面を組み合わせた土地利用分析、(2)景観構成要素として作付け、 農地の形状、水利を中心とした歴史的な基盤整備などの分析項目 の多様化、以上の 2 点において 4.4 でとりあげたテルニ盆地の方法 論を踏襲し、進化させた。上記(1)、(2)の調查結果から、ローマ時代 とそれ以前、中世の時代、ルネサンス期から 19 世紀末、1960 年、 1980 年という5 葉からなるコムーネ全域の歴史地図を作成した。 各時代の地図から、社会的経済的背景や宗教の影響力によって、チェ ントロ・ストリコと農業地域の関係が大きく変容したことを明らか にした。先人はチェントロ・ストリコには常に住み続けたものの、 ローマ人に開拓された平野部の農地は、中世の時代には戦場とな り、丘陵地帯や山地に新たな農地が開拓された。ルネサンス期の平 和の到来とともに平野部は再び農業の主たる対象となり、基盤整備 にも投資され、今日のパエサッジョの礎が形成された。20世紀に 入ると農業地域における建築行為や作付けの変更により、パエサッ ジョの断片化が進んだ。新たな視点として、断片化が進んだ農業地 域であっても、景観構成要素が豊富にあれば、相互に補い緩やかな 連続性により面的な広がりが維持されることを指摘した。こうした 農業地域の立地、基盤整備、農場の全体像、農地の区画、作付け、 建造物など、歴史的な変遷を含めてパエサッジョを成立させてきた、 多様な担い手の結びつきやコミュニティの仕組みを、ファリーニは 社会的テッスート注16、その経済の循環を経済的テッスートと呼んだ。

ファリーニは本研究結果を踏まえ、農業地域のパエサッジョ・ス トリコを、より積極的かつ詳細に保護する必要を唱え、都市計画提 案をした。同提案は採用され、2000 年にコムーネ全域の 8 割以上を 文化的資産、2 割弱を緩衝ゾーンとして世界文化遺産に登録する根 拠となり、のちに保存管理計画として採用された。2011年には、 より精度を高めた「景観の質のためのガイドライン」となった。

\section{1 .2 県域調整計画による制御}

ディ・ピエトロは 1996 年から翌年にかけて、36 コムーネからなる シエナ県が策定した地域調整計画において、パエサッジョを保存す る評価基準を、(1)県全域を分割した 16 の景域=ウニタ・パエジスティ ケ」と 18 の「景観類型ニティピ・ディ・パエサッジョ」、(2)景観重要地 区（図 4)、(3)田園に立地する単体の歴史的建造物評価リス卜、(4)農 地の類型化、以上の 4 点にとりまとめた。(1)、(2)は土地利用、(3)、(4) は景観構成要素をつうじてパエサッジョを制御する組み立てだった。

景域を、歴史に裏付けられた文化的アイデンティティをもつ、安 定した持続可能な定住環境と位置付けた。その範囲を、チェントロ・ ストリコを含む市街地と、それらに帰属していた農業地域と自然地 域を一体とした土地利用から定めた。景観類型を、数種類の農地と 林地、市街地からなる今日の土地利用と、地質と岩質いう 2 つ指 標からなる範囲とした。いずれもコムーネ以上に広く、複数のコムー ネにまたがり、行政界とは一致せず、相互にも一致しない類型だっ た。景観重要地区はテリトーリオに点在する小規模なチェントロ・ 
ストリコと、その周囲の農地を一体の保存地区としたゾーニングだ った。田園に立地する単体の歴史的建造物リス卜は、a) 用途、地形 図とカタストの照合による歴史的評価、 b-1) 保存状態、b-2) 内外の 改造の状態、b-3）景観構成要素としての今日的評価、c) 保存を担保 しうる既存法の有無、以上の 3 つ評価基準から作成した。農地は 15 通りの類型に分類した。そのうち 20 世紀初頭までに完成した 3 種 類の歴史的な農地の類型を、テッスートと同義語であるテッシトゥ ーラとよび、パエサッジョの全体像における重要性を際立たせた。

\section{1 .3 本節の考察}

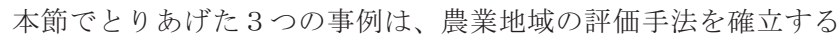
ことによって、コムーネや県のテリトーリオ全域をパエサッジョ・ ストリコとして制御しうることを示した、先駆的事例となった。

カルツォラーリの成果は、土地断面と水系のシステムを根拠とし て、歴史的な農業地域を環境面から面的に評価した点にあった。

ファリーニとディ・ピエトロに共通する成果は、個票調查に基づ いて 70 年代から取り組んだ、土地利用と景観構成要素を結びつける 研究のうち、とくに(1)類型学的分析の対象の多様化、(2)形態学的分 析を裏付けとした段階的スケールの確定、(3)農業地域のテッスート の意味付け、以上 $3 つ の$ 側面を計画手法として実現した点にあった。

ディ・ピエトロの成果は、景域と景観重要地区を明確に線引きし た点にあった。デッティによる中世の都市国家のテリトーリオ研究 にたいし、前者は社会的経済的な結びつきのあった複数の中世の都 市国家のテリトーリオを、後者はチェントロ・ストリコと農業地域 を一体として制御するための具体的分析結果を導いたと考えられる。

ファリーニの成果は、パエサッジョ・ストリコとは視覚的に認識 できるひとつの眺望ではなく、異なる時代の遺構が混在し、(1)文化 の変節ごとに異なる土地利用や生活様式、(2)現状とは異なる分布を 示していた先人の定住環境、(3)景観構成要素の多様化から理解しう る面的な連続性、以上 3 点を読みとりうることを明らかにした点に ある。併せてテリトーリオの空間特性を支える社会的経済的テッス ートという概念を刷新し、世に問うたことも注目に值する。

\section{2 文化的景観としてのテリトーリオ・ストリコ}

1990 年代に入り、EUにおけるパエサッジョの捉え方が変化した。 その背景には、(1) 1991 年の欧州環境会議、1994 年の地中海景観憲章、 同年の国際自然保護連合の研究報告をへて、2000 年に欧州景観条約 が制定されたこと、(2) 1992 年にユネスコの世界文化遺産のカテゴリ 一に文化的景観が設立されたこと、以上の 2 つの経緯があった。ユ ネスコは欧州景観条約を受け、2003 年以降の世界文化遺産の登録申 請の条件に保存管理計画の策定を加えた。イタリア政府は 2006 年に、 過去に登録した世界文化遺産にも、同計画の策定を義務づけた。

同国の地理学者らは3.1.3 でとりあげたように、第 1 次産業によ る人為的なパエサッジョを常に、文化的景観と捉えてきた。ただし その客観的評価基準は、サウアーに着目した世界遺産委員会による 世界文化遺産の指針によって、はじめてもたらされたと考えて良い。

\section{2.1 文化的景観としてのオルチア川流域}

テリトーリオの表徴をパエサッジョと捉えて都市・地域計画の手 法で制御する方法は、社会的テッスートを十分に活かしえず、地域 づくりの手段として限界があることを、ファリーニは指摘した。ユ ネスコの文化的景観の保存管理計画を連動させ、パエサッジョ・ス トリコを、より積極的に地域づくりに役立てる策を提唱した。
事例とするトスカーナ州シエナ県オルチア川流域芸術・自然・文 化公園は、5つのコムーネ（カスティリオーネ・ドルチア市、モン タルチーノ市、ピエンツァ市、ラディコーファニ市、サン・クイリ コ・ドルチア市）の 9 割以上の面積を占める。 5 つのコムーネとシ エナ県は自主管理型自然保護区 (ANPIL) に分類される公園の設立を 1999年にトスカーナ州に申請し、2004年に世界文化遺産に登録した。

保存管理計画を策定したファリーニは、5.1.2 でとりあげたディ・ ピエトロによる調査結果を活用しつつ、この地域のパエサッジョ・ ストリコを、(1)オルチア川を囲んで多くの都市国家が分布していた 時代のテッスート、(2)シエナ共和国による統一後のテッスート、(3) 巡礼街道とその周辺のテッスート、(4)折半小作制に端を発した農業 地域としてのテッスート、以上の 4 つのテッスートと、その社会的 テッスートから成り立つとした。オルチア川流域は当初の自然保護 の対象のみならず、歴史と環境というパエサッジョの 2 つ側面が 密接に関係し、均衡してきたことを明らかにした。眺望の添景に過 ぎなかった農業地域こそ、5つのコムーネの歴史を担い、持続可能 な基幹産業の表徴であることを導き、(1)各々のチェントロ・ストリコ とその農地がテリトーリオを形成していたこと、(2)シエナ共和国の 支配下に入り、未開拓だったオルチア川両岸の低地を囲む、ひとつ の広域なテリトーリオを形成したこと、(3)それ以来、自然保護区の 設立まで農地の開拓が続いたこと、以上の変遷を浮き彫りにした。

ファリーニはさらに、テリトーリオの社会的テッスート、経済的 テッスートの持続を促す仕組みを提案をした。それまでの自然を保 護し眺望を愛でる公園から、健全な基幹産業の維持を目的とした農 業公園人、その運営主旨を切り替える内容だった。テリトーリオの 維持と成長管理の面で、(1)農業の再評価や支援に結びつく起業者や 産業の誘致を支援できるコミュニティの体制を設けること、(2)公園 管理団体として設立されたオルチア川流域有限会社を文化的景観の 管理団体とし、地域のマネージメントにも活用すること、(3)州、県、 コムーネの策定する都市・地域計画によってテリトーリオ全域を制 御すること、以上の 3 点を促した。世界遺産登録以降、オルチア川 流域における取り組みは成功を収めている。ただしこの事例は他に 類似例がなく、その手法の普及については今後の展開を見守りたい。

\section{6. おわりに}

以上の通時的研究より、(1)復興の展望に記されたパエサッジョ・ ストリコの保存は、都市分析の手法を応用した農業地域の入念な研 究により可能になったこと、(2)同展望で提唱された 3 つの枠組みが 連動し、テリトーリオ・ストリコを活用しえたこと、(3)パエサッジ ヨ・ストリコとテリトーリオ・ストリコが一致をみたことから、前 者の審美的、歴史的、環境的価值と、後者の社会的、経済的テッスー 卜という価值を、相互に付与しあう関係を導いたことを理解しえた。

その過程で(1)テリトーリオの有機的な全体像がテッスートとして 論じられたこと、(2)類型学、形態学を組み合わせ、土地利用と景観 構成要素の双方から分析する手法が確立されたことを俯瞰しえた。

デッティによる中世の都市国家、カルツォラーリによる行政界、 または歴史と自然のシステム、ベネーヴォロによるマトリクスは、 いずれもムラトーリが文明論に基づき定義した幾段階かのテリトー リオに含まれ、ディ・ピエトロ、ファリーニ、ジャニギアンによる 文化的景観は、そのある段階を広域かつ詳細に記述したといえる。 
市街地、農業地域、周辺の自然からなるテリトーリオ・ストリコは、 自然、社会、経済が合致した循環のシステムとして再評価され、21 世紀に向けた価值観を伴うに至った。この成果は文化的景観の保存 活用と同じ展望を有するというファリーニの発見にも結びついた。

拙稿において俯瞰したイタリアの農業地域の保存活用の歩みは、 たとえば我が国の農業を基幹産業とする自治体において、歴史的景 観を生かした地域づくりを推進するうえで、参照に值すると考える。 謝辞

本稿を記すにあたり、とくにローマ大学教授パオラ・ファリーニ 氏には惜しみない協力を、ヴェネツィア建築大学教授ジョルジョ・ ジャニギアン氏にも協力を頂きました。深い謝意をここに記します。

注

1）陣内秀信「都市の思想の転換」，『都市の思想の転換点としての保存（都市 住宅 7607)』マルチェッロ・ヴィットリー二責任編集，陣内編集協力, 鹿島出 版会, 1976.7. 陣内『都市のルネサンス』中公新書, 1978.5a. 陣内『イタリア 都市再生の論理（SD 選書 147）』鹿島出版会, 1978.11b. 田島学＆陣内「イ タリア都市形成史研究」『地中海学研究亚』地中海学会, 1980. 野口昌夫： 「イタリア歷史的都市の保存再生計画 (パオラ・ファリーニ日本講演録)」『SPAZTO』 46 号, 本オリベッティ広報部, 1993.12, pp.22-34.『イタリアの都市再生（造景 別冊 1)』陣内監修，ファリーニ，パオラ\&植田曉編集，建築資料研究社，1998. 11. 宗田好史『にぎわいを呼ぶイタリアのまちづくり一歴史的景観の再生と商業政 策』学芸出版, 2000.1. 植田「都市計画と景観活用の新しい展開一イタリア・グッ ビオ市を例に」『季刊まちづくり』15 号, 学芸出版社, 2007.6. 野口『イタリア 都市の諸相』刀水書房，2008．植田「イタリアにおける都市・地域研究の変 遷史一チェントロ・ストリコからテリトーリオへ」『水都学而』陣内，高村 雅彦編集，法政大学出版局, 2015.2, pp.167-209.

2）宗田「イタリア・ガラッソ法と景観計画」『リゾート開発と景観保全法（公 害研究)』18(1), 岩波書店, 1988.7, pp.15-27. 温井亨「ガラッソ法とイタリ アの風景保全」『造園雑誌』56(5), 1993.3, pp.79-84. 宮脇勝; 西村幸夫「イ タリアにおける風景計画の展開 イタリアにおける歴史的環境保全計画に関 する研究その 1」『日本建築学会計画系論文集』第 466 号, 1994, pp.123-132.

3）宗田：『なぜイタリアの村は美しく元気なのか一市民のスロー志向に応え た農村の選択』学芸出版社, 2012.8 .

4）ファリーニ「イタリアの歴史的田園地域におけるアクティヴな保存」『エ コロジーと歴史にもとづく地域デザイン』（法政大学大学院エコ地域デザイ ン研究所編, 陣内監修), 学芸出版社, 2004.6. 植田「景観の保全計画と運 用計画の複合性に関する研究, イタリア・トスカーナ州シエナ県オルチヤ 川流域地域自然保護区を事例として」『景観のフロンティア』(総合論文誌 第 3 号), 日本建築学会, 2005.2. ファリー二, 玉井美子翻訳, 植田翻訳協力・ 監修『第 4 回サス研フォーラム講演録・サステイナビリティと地域再生計 画・イタリアにおけるオルチア川流域とマントヴァの新たな経験』法政大学, 2010.12. 植田：「オルチア川流域：丘陵地に広がる防衛システムと農村景 観地場産業の構造強化と環境保護を両立寸る地域づくり」，日本建築学会 編『未来の景を育てる挑戦〜地域づくりと文化的景観の保全〜』技報堂出版, 2011.8. ファリーニ「オルチア渓谷の文化的景観一広域景観のための統合的 保存管理ストラテジー：文化的景観のまもりかた〜営みの真実性はどのよ らに保たれるのか」『2014 年度日本建築学会大会（近畿）農村計画部門パ ネルディスカッション資料集』日本建築学会農村計画委員会農山漁村文化 景観小委員会,pp.5-11, 2014.9. 植田「農業地域とそのテリトーリオの動的真 正性 : アッシジとオルチア川流域の文化的景観」ib.id., pp.41-45.

5）第 2 章の執筆にあたり、参照した中心的文献を以下に列記する。Zocca, Mario: Elementi per uno studio dellurbanistica medivevale in Italia, Roma, Armani di M. Courrier, 1938.11. Piccinato, Luigi: Urbanistica Medioevale, Firenze, G.C. Sansoni Editore, 1943.5. Della Rocea, Aldo; Muratori, Saverio; Piocinato; Ridolfi, Mario; De Paoli, Paolo Rossi; Tadolini, Scipione; Tedeschi, Enrico \& Zocca: Aspetti urbanistici ed edilizi della ricostruzione, Roma, 1944-45, 本宣言文は Giovanni Bentivoglio によって復刻された。Viterbo, Lo stabilimento tipolitografico Agnesotri, 2007.3. Bardet, Gaston: "Il tessuto urbano, nuovi metodi di analisi e sintesi," Urbanistica N.4, Roma, INU, pp.20-34, 1950. Aymonino, Carlo: La città di Padova, Saggio di analisi urbana, Roma, Officina, 1970. Rossi, Aldo: L'architettura della città, Padova, Marsilio,1966. Muratori: Storia e critica dell'architettura contemporanea, Roma, Centro studi di storia urbanistica (C.S.SI) ,1980 本書はムラトーリの初期の論文集にあたり、収録された 4 編の論文 (Disegno storico degli sviluppi architettonici attuali(1944), Saggi di critica dell'architettura contemporanea (1946a), La valutazione dell'opera architettonica (1946b), Saggi di metodo nello studio dell'architettura(1946c)）は、後の研究の礎となった。Muratori: "vita e storia della città," Rassegna critica di architettura N.11-12, Roma, M.Danesi. 1950. pp.3-54. この 時期にムラトーリは独自の建築類型を考案し (Muratori(1946c))、テッスート の概要を記した（Muratori(1950)）。Muratori: Studi per una operante storia urbana di Venezia, Venezia, Istituto Poligrafico dello Stato, Libreria dello Stato, 1959. Muratori: Studi per una operante storia urbana di Roma, Roma, Consiglio Nazionale delle Ricerche, 1963. ム ラトーリは建築類型とテッスートの概念を融合し、テッスート・ウルバー ノ論を確立し、陣内（1978b）が紹介した 2 つのフィルドワーク「ヴェネ ツィアの実践的都市史の研究 (Muratori(1959)) 」、「ローマの実践的都市史の研 究 (Muratori(1963)」で、その可能性を実証した。AAVV:: "Difesa e valorizzazione del paesaggio urbano e rurale," Urbanistica N.23, Torino, INU, 1958.3, pp.115-120. Samona, Giuseppe, et al.: "salvaguardia e il risanamento dei centri storico-artistici," Urbanistica N.32, Torino, INU, 1960.12, pp.65-84. Anon: "Il convegno sulla salvaguardia e il risanamento dei centri storico-artistici, dichiarazione finale,"ib.id.,pp. 65-66.この宣言は後に「グッビオ憲 章」と呼ばれるようになった。全文の邦訳は陣内監修、ファリーニ、植田共 同編集（1988）「グッビオ憲章60（全文)」op.cit., p.154. Marconi, Plinio: Il territorio della media valle del Tevere, la pianificazione territoriale comprensoriale, Roma, Tipografia regionale, 1966. 大谷幸夫他： 集住体モノグラフィ 3、語りかける中世イタリア の山岳都市・テベレ川流域（都市住宅別冊），鹿島出版会，1976.6. Detti, Edoardo: "Lo studio degli insediamenti minori. Alcune comunità della Lunigiana e della Versilia," Urbanistica N.22, Roma, INU, 1957.7a, P.111, P.120. Detti: "Urbanistica medievale minore," La critica d'arte N.24, Valleochi Editore, Firenze, 1957.11-12b, pp.499-500, p502. Coppa Mario \& Ottolenghi Marinella: "Il contado pergino, interpretazione di un comprensorio medioevale," Urbanistica N. 26, Roma, 1959.3, pp.38-53. Coppa: I centri storici nella Valle del Clitunno, materiale grigio, Perugia, CRPSEU, 1962, (Ricerche sullurbanistica ed il turismo,N.10.2). Astengo, Giovanni: Urbanistica N.24-25, Torino, INU, 1958, p.2, pp.9-28, pp.79-80, p.85. De Carlo, Giancarlo: Urbino, La Storia di Una città e il piano della sua evoluzione urbanistica, Milano, Marsilio, 1966, pp.105-106, pp.117-119, pp.128-137, pp.209-213. De Carlo: "Problemi del P.R.G. di Urbino," Questioni di architettura e urbanistica, Segrate, Maggiori editore, 2008, pp.103-129. 6）この宣言において歴史的芸術的街区（チェントロ・ストリコ・アルティ スティコ - centro storico artistico）という表現が初めて用いられ、歴史的市 街地そのものが芸術的に価值あることが明文化された。

7） バルデはテッスート・ウルバーノを、地割りを基本として分析した。カタ ストの個票ごとの調査、住民の社会的属性、個々の建造物の利用状況の調 査を組み合わせ、市街地をひとつの有機体として把握できると論じた。ま たその結果を市街地の規模を問わず、ダイアグラムとして描きうるとした。 ムラトーリはテッスート・ウルバーノを、都市の有機的な全体像と定義した。 都市の本質を時間的な連続性と論じ、ひとつひとつの都市に備わる固有の 歴史的連続性を研究することによってのみ、その有機性と成長を捉えうる、 と説いた。陣内はバルデ、ムラトーリ双方の論旨より都市組織という邦訳 を与えた。「歴史の中で長い時間を掛けて形成されてきた有機体として見る。 すなわち、それを構成する各部分が相互に関係を持ちながら変化、置換を 続け、全体として調和的に緩やかな成長、変化を続けていくものとして捉 えるのである。都市有機体の細胞、寸なわち都市の構成単位の建築は、そ れだけで独立して形成されるのではなく、都市のトータルな環境系の中で 形づくられるものである。その環境系は厳密には、地割、街区形態、空地・ 道路システムの中に建築が集合し、秩序づけられながら織り成されている 都市組織として捉えられる。(陣内 1978a)」、「(歴史地区) を構成している 建築、道、広場等によって織り成される（陣内 1978b)」と説明した。

8）第 3 章の執筆にあたり、参照した中心的文献を以下に列記する。Benevolo, Leonardo(1958): "il piano regolatore," Urbanistica N.23, Torino, INU, 1958.3, p.159. Aldo Sestini: Il Paesaggio, Conosci l'Italia vol.7, Milano, Touring Club Italiano, 1963. Guido Ferrara: L'architettura del paesaggio italiano, Padova, Marsilio, 1968. カンポレ ージ, ピエーロ (中山悦子訳)：「風景の誕生」筑摩書房, 1997.6. Croce, Benedetto: L'Estetica come scienza dell'espressione e linguistica generale, sesta edizione, Bari, Gius. Laterza \& Figli, 1928, p.17. 本書の第 1 版は 1902 年に R. Sandron より出版された。 Settis, Salvatore: Benedetto Croce ministro e la prima legge sulla tutela del paesaggio, Venezia, 2011. Parpagiiolo, Luigi: Elementi di legislazione agraria e notizie sui trasporti e sulle dogane, Roma, Libreria del policlinico, 1904. Parpaghiolo: Codice delle antichità e degli oggetti di arte, Roma, Ermanno Loescher \& C., 1913, pp.21-23, p.84. Croce: Per la tutela delle bellezze naturalie degli immobili di particolare interesse storico, 1920. 本稿は同年 9 月 25 日上院 における立法にむけて議案を提出した際の原稿にあたる。Falini:Ambiente, cultura e paesaggio - un caso Europeo. 2008.2. 同月 9 日に、ふれあいセンターびらとりで 開催された平取文化的景観フォーラム基調講演より（植田による全文翻訳 付パワーポイントを上映)。Parpagiolo: Intorno alla legge in difesa delle bellezze naturali e del paesaggio,1931. 本稿はパルパリオロによる講演原稿にあたる。Assunto, Rosario: 
"il tempo della natura e la sua imagine," il paesaggio e l'estetica, vol.1, natura e storia, Napoli, Giannini editore, 1973, pp.71-145. Giacomini, Valerio: La flora - Conosci l'Italia vol.2, Touring Club italiano, Milano, 1958. p.9. Giacomini: "Agricoltura e ambiente - l'anno europeo; per la conservazione della natura," Agricoltura N.7, Roma, Istututo di tecnica e propaganda agraria, 1970, pp.1-8. Giacomini: "Per un parco nazionale dell'Etna," Tecnica Agricola A. XVIII, 1, Catania, Associazione dei dottori in scienze agrarie della provincia di Catania, 1966a, p.11. Giacomini: "L'Etna Parco Nazionale: un paesaggio incomparabile da salvare e valorizzare," Italia Forestale e Montana, Anno XXI, 3, Firenze, Academia Italiana di Scienze Forestali, 1966b, p.29. Giacomini: Conservazione della natura e del paesaggio, Trento, Museo tridentino di scienza naturali, 1967, pp.26-27. Romani, Valerio: Storia ed evoluzione del concetto di paesaggio Paesaggio e pianificazione - Il paesaggio bresciano trasformazione e problemi, Brescia, ATENEO, 1991. Nice, Bruno: "geografia e urbanistica," Urbanistica N.3, Roma, INU, 1950, pp.7-10. 竹内啓一「イタリアにおける地理学」『人文地理』vol.17, No.5, pp.518537, 1965. Biasutti, Renato: Il paesaggio terrestre, 2nd ed., Torino, UTET, 1962, pp.155-159. Sestini: "Il paesaggio antropogeografico come forma d'equilibrio," Bollettino della Società geografica italiana, 1947, pp.1-8. Sereni, Emilio: Vecchio e nuovo nelle campagne italiane, Editori Riuniti, Roma, 1956, pp. 63-99, pp.273-370. 本書の邦訳に、エミリオ・セレ 一二：中村丈夫, 植原義信訳,「イタリア農業の構造的改革一イタリア農村の 古いものと新しいもの」（三一書房, 1959, pp.47-71, pp.187-250) がある。Sereni: Storia del paesaggio agrario italiano, Bari, Laterza, 1961, p.98, pp.381-387. Gambi, Lucio: Critica ai concetti geografici di paesaggio umano, Faenza, F.lli Lega, 1961. Gambi: "I valori storici dei quadri ambientali," Storia d'Italia vol.1, Torino, Giulio Enaudi Editore, 1972, pp.3-60. Turri, Eugenio: Antropologia del paesaggio, Milano, Edizioni di Comurutà, 1974, pp.11-23. Sauer, Carl Ortwin: The Morphology of Landscape, University of California publications in geography Vol.2, No.2, Berkeley, University of California press, 1925.10, pp.19-53. Turri: Semiologia del paesaggio italiano, Venezia: Marsilio Editore, 1979(1mo ed.), 2014(3zo ed.). Calzolari, "paesaggio," "paesistica," "parco," Dizionario enciclopedico di architettura e urbanistica IV, Roma, Istituto editoriale romano, 1969, pp.333-334, pp.335339. Calzolari: "Concetto di paesaggio e paesistica," Architettura del Paesaggio, Firenze, La Nuova Italia, 1974, pp.73-88. Muratori: Civiltà e territorio, Roma, C.S.S.U., 1967, pp.196-198. Muratori: Autocoscienza e realtà nella storia delle ecumeni civili, lizione 197172, Marinucci, Guido (a cura), Roma: C.S.S.U., 1976, pp. 426-457. Croce(1928): pp.6074, pp.141-152. Muratori(1976): pp.56-58, pp.427-452. 陣 内 (1978a): p.17. Maretto, Paolo: Nell'architettura, Firenze,Teorema, 1973, pp.222-237. Caniggia, Gianfranco: Lettura di una città: Como, Roma,C.S.S.U., 1963, pp.33-39. Caniggia: Strutture dello spazio antropico, Uniedit, Firenze,1976, pp.111-114, p.147, pp.191-195, p.217. Cataldi, Giancarlo: Saverio Muratori: $\operatorname{architetetto~(1910-1973),~Firenze,~1984,pp.110-113,~126-137.~}$

9）ジャコミーニは、国内的には生物圈保存地域（riserva della biosfera）設立 を目的とした国立公園法の制定にむけて、国際的にはユネスコの「人間と 生物圈計画 (MAB-Man and the Biosphere Program)」の中心的委員として、イ タリアの自然保護区の設立に貢献した。1974 年には後者の立場で、後にエ コロジカル・ネットワークと呼ばれる概念を提唱したという。

10）ムラトーリは人の精神が論理性、経済性、倫理性、審美性、以上の 4 つ の側面から成り立つとした。これはクローチェによる直観的認識行為（審 美性)、概念的認識行為 (論理性)、経済的行為 (経済性)、道徳的行為（倫理 性）からなる 4 つの精神活動の定義と順位を応用した考えだった。テリト ーリオの形成には、審美性以外の 3 要素が優先するとムラトーリは論じ、 クローチェによる順位を、論理性を最優位、審美性を最下位におきかえた。

11）ムラトーリは 4 つ価值観を 2 つの時代に区分した。前半をギリシア文 明による芸術、都市国家の概念、科学、形而上学的論理とした。後半をロー マ時代より今日まで続く、私法、公法、教会法、絶対君主制からローマ法 大全にいたるローマ時代の幅広い法体系による価值観、とした。

12）第 4 章の執筆にあたり、参照した中心的文献を以下に列記する。Detti; Di Pietro, Gian Franco \& Fanelli, Giovanni: Città murate e sviluppo contemporaneo - 42 centri della Toscana, Milano, C.I.S.C.U., 1968. Detti: "Città murate e sviluppo contemporaneo," ib.id., pp.7-11. Di Pietro: "Gli insediamenti e gli assetti territoriali medioevali in Toscana-Ipotesi per una classificazione," ib.id. pp.16-24. Coppa; Giaccomini; \& Falini: Studio preliminare piano territoriale paesistico della costiera amalfitana, Roma, s.n.e., 1972. Giacomini: "I paesaggi vegitali," ibid, pp.81-90. Falini: "Analisi dei centri abitate il loro contesto ambientale, Elementi di formazione del campo," ib.id., pp.119128. Falini: "Elementi di formalizzazione del campo. Le figure ambientali," ib.id, pp.131-161. Calzolari \& Olivieri, Massimo: Piano per il parco dell' Appia Antica, Roma, Italia nostra (sezione di Roma), 1984. Calzolari: "La proposta di piano per il parco dell'Appia antica," ib.id, pp.157175. Battista, Antonio \& Giacomini: "il paesaggio vegetale del comprensorio dellappia antica," ib.id., pp.47-54. Giuseppe Gisotto: "Analisi ecologica e utilizzazioni prevedibili del territorio," ib.id, pp.55-58. Benevolo: Roma da ieri a domani, Bari, Laterza, 1971. Di Pietro \& Fanelli: La Valle Tiberina toscana (a cura dell'Ente provinciale per il turismo), Firenze, Le Arti Grafiche
Alinari Bagioni, 1973.11. Di Pietro: "La formazione storica del territorio della Valle Tiberina Toscana - Le strutture territoriali," ib.id., pp.XIX-XIL Di Pietro: "Le strutture territoriali," ib.id., pp.xxxiii-xiv. Anon. (Provincia autonoma di Trento, servizi dell'urbanistica): Il ricupero degli insediamenti storici come alternativa allo spreco delle risorse, Trento, Pezzini, 1981. Anon: "lanalisi dei centri aggregati," ib.id., pp.153-155. Anon."'Proposta di metodo per lanalisi del territorio Trentino," ib.id., pp.117-121. Falini; Grifoni Cristina \& Lomoro Annarita: "Struttura agrarie storiche e fonti catastali geodetiche, alcuni questioni e proposte di metodo," Fonti per lo studio del paesaggio agrario, Martinelli, Roberta \& Nuti, Lucia (a cura), Lucca, CISCU, 1981a.9, pp.345-356. Falini; Grifoni \& Lomoro: "Conservation planning for the countryside, a preliminary report of an experimental study of the Terni Basin," Landscape Planning 7, Amsterdam, Elsevier Scientific publishing company, 1980. Falini; Grifoni \& Lomoro: "Tipologie agrarie storiche e pianificazione territoriale," agricoltura ambiente N.11 annoIII, Roma, F.lli. Palombi, 1981b.6. Gianighian, Giorgio: "Ricerche sulla conservazione e sul restauro territoriale nell'area veneta," La scienza e la conservazione dei beni culturali, Padova, Marsilio, 1979. Gianighian: "Ritratto delle cose di campagna/2, case e colture a Casteluocio (Asolo) 1713-1841," Parametro N.90, Faenza, Faenza editorice, pp.26-35, pp.57-58, 1980.10. (ジャニギアンの 研究は例えば Dario Paolucci, Matteo: "Il paesaggio agrario tra conservazione e restauro," Urbanistica N.120, Roma, INU Edizioni srl, 2003.4, p.91-101 として引き継がれた）

13）農業地域を都市緑地として担保する手法には、宗田好史が早い時期に着 目し、日本に紹介した。宗田（1988 年）p. 22 を参照されたい。

14）環境としてのパエサッジョにたいする取り組みが世界的に共通する価值 を目指したのにたいし、歴史としてのパエサッジョの取り組みは、イタリ ア独自の文化の表徴の保存と、今日的な価值付けを目指した。環境と歴史 の概念のうち、前者を優位に扱った先駆的都市計画家としてマルチェッロ・ ヴィットリーニやジュゼッペ・カンポス・ヴェヌーティ、その次世代とし てロベルト・ガンビーノやグイド・フェッラーラらがいる。

15）第 5 章の執筆にあたり、参照した中心的文献を以下に列記する。植田 (2015): p.187-190. Comune di Siena: Piano regolatore generale, Siena, 1990. Gabellini, Patrizia: "Il progetto di piano," Urbanistica N.99, Milano:INU, pp.32-50, 1990.6. Di Biagi, Paola: "Antologia," ib.id., pp.51-81. Rallo, Daniele: "Progetto V.en.u.s. Valutazione della eseguibilità dei nodi urbanistici di Siena," ib.id., p. 81. Secchi, Bernardo, "Siena," ib.id., pp.82-88. Falini: "Nuovi piani e riquarificazione dellesistente," Rassegna di architettura e urbanistica anno XXIV n.71-72, Roma, Kappa, 1990.9-12,pp.31-57. ファリーニ「シエナ 一中世山岳都市の再生一新しい文脈で都市を読む」陣内監修, ファリーニ・ 植田編集 (1998), pp. 69-72.Calzolari: "Siena, paesaggi dei tufi, delle crete e dei calcari," Rassegna di architettura e urbanistica anno XXVII n.80-81, Roma, Kappa, pp.35-50, 1993.511. カルツォラーリ：「シエナの農業景観」陣内監修, ファリーニ\&植田編集 (1998),pp.138-141. Falini: Comune di Assisi - Variante generale al piano regolatore generare I valori storico ambientali del territorio rurale, 1994. Falini:"'ll territorio storico di Assisi :Una <descrizione di sfondo> per il nuovo PRG," Rassegna di architettura e urbanistica anno XXIX n.86/87, Roma, Kappa, 1995.5-12. ファリーニ：アッシジの農業景観，宗田訳，陣内 監修，ファリーニ\&植田編集 (1998), pp.142-147. Comune di Assisi: Linee guida per la qualità del paesaggio di Assisi, 2011.11. Ufficio di piano di PTC di Provincia di Siena: Quadro conoscitivo del Piano territoriale coordinamento provinciale, 1997. Di Pietro, Gian Franco \& Gobbo, Teresa"Il paesaggio come fondamento del Ptc di Siena," Urbanistica Quaderni n.36, Roma, INU, 2002. UNECE: Conclusions of the conference "Environment for Europe," Dobris, 1991.6. http:/www.unece.org/fileadmin/DAM/env/efe/history\%20of\%20EfE/Dobris.E.pdf. (accessed 2009-05-10). Le Regioni dell'Andalusia, del Languedoc-Roussillon e della Toscana: Carta del paesaggio mediterraneo, 1994.3, http://www3.unisi.it/did/dip-direcon/carta_ medit.pdf. (accessed 2009-05-10). IUCN:"Protected areas and key sectors of public policy agriculture," Parks for Life : Action for Protected Areas in Europe: Action for Protected Areas in Europe, Glan, Martinpiano oy, pp.30-34, 1994. Fowler, Peter J.: World Heritage Cultural Landscapes 1992-2002, Paris, UNESCO World Heritage Centre, pp.18-23, 2003. Congress of the Council of Europe: Convenzione europea del paesaggio, Firenze, 2000.10. http://www. convenzioneeuropeapaesaggio.beniculturali.it/uploads/2010_10_12_11_22_02.pdf. (accessed 2009-05-10). World heritage committee: Convention concerning the protection of the world cultural and natural heritage fifteenth session, Carthage, 1991.12. Falini \& Val d'Orcia srl: Piano di gestione della Val d'Orcia, 2002. Falini \& Val d'Orcia srl: Piano di gestione della Val d'Orcia, 2010. ファリーニ (2010.12), pp.14-18. ファリーニ (2014.9), pp.5-11.

16）ムラトーリ（(1967), p. 298 参照) は社会的テッスートという用語に触れ、 テリトーリオの概念に関連づけた。一般的にはテッスート・ウルバーノと 対をなすかたちで 1970 年代から住民参加に高い関心を示したデ・カルロをは じめとした建築家によって活用された。当時は参加型まちづくりの地権者 や市民による組織体をさす場合が多かった。ファリーニはパエサッジョを 形成する、幅広い担い手による社会的な全体像をひとつの組織体として再 定義した。ただしテッスート・ウルバーノが社会的意味合いを含むように、 社会的テッスートもテッスート・テリトアーレを俯瞰的に示す場合もある。 


\title{
DIACHRONIC STUDY OF CONSERVATION AND UTILIZATION OF HISTORICAL LANDSCAPE IN AGRICULTURAL REGIONS WITH ITALIAN TERRITORIAL PLANNING AFTER SECOND WORLD WAR
}

\author{
Satoshi UEDA* \\ * NPO Network for community development with landscape, M.Eng.
}

In Italy, the conservation and utilization of regional historical resources are values that have always coexisted with modern urban planning. They are more than physical accomplishments that value the authenticity of architecture, buildings, cities and landscapes. Their purpose is to conserve the historical regional community and its economic activities, give added value and exert synergic effects to aim for the recuperation as a sustainable region. They are similar to the particular vision of the recent working in Japan that is being referred to as "regional development that draws on history." This paper attempts to shed light on the mechanism of how regional management came to be by studying the genealogy of urban and regional planning. The focus of the study target will be the agricultural region.

Even before World War II, urban planners were aware of this subject. With post-war reconstruction, they commenced their studies, aiming for the conservation of the historical landscape (paesaggio storico) in the agricultural region. The post-war agricultural region underwent a major transformation due to changes in the scope of the plowed land and in planting which in turn were characterized by background factors such as population declines. To analyze the historical landscape of the agricultural region, urban planners employed a method to analyze and examine the ancient cadastre and cadastral map (catasto, cabreo, etc.), the produced results of past analyses and planning of historical urban centers. They also used the "tessuto" (based on the urban tissue concept - tessuto urbano) concept and its underlying two methods to draw a whole picture of the agricultural region, building typology (tipologia edilizia) and urban morphology (morfologia urbana) .

Until the 1960's, urban planners, led by the National Urban Planning Institution, worked to formulate a reconstruction perspective and an actual scheme that drew on history. Concurrently, they engaged in advanced research and planning. By the early 1970's, aiming for the conservation of historical landscapes, they had established a modern concept for the landscape and region, having been influenced by aesthetic philosophy, biosphere-based botany and human geography. In the early 1980's, a planning method from a botanical perspective and one from a human geography perspective were set up. Both planning methods value history but their differences lie in the definition of the landscape unit. The planners of the latter, in particular, used a method of building typology to analyze both the historical produce of the agricultural region and historical planting technology evolving the "tessuto territoriale" (regional tissue) concept. By the latter 1980's, many citizens came to reassess the value of the historical region (territorio storico). This led to civilian movements such as the leading slow food movement. With EU's policy shift to environmental farming, it was now possible to use urban management to sustain agricultural regions that possessed historical landscapes. As a result, since the 1990's, innovating a concept, the "tessuto sociale" (social tissue) which mainly used for a participation planning method specially in 1970's, historical landscapes of agricultural regions have been conserved in urban and regional planning through the master urban plan and such.

A topic that emerged next to manage the agricultural region was the nurturing of leaders, construction of a community recuperation model and sharing of this methodology. After 2006, urban planners came up with urban regional planning methods to connect the preservation of physical historical landscapes, a UNESCO world cultural heritage, to the recuperation of regional social and economic foundations. They accomplished this through the management plan of cultural heritages and by using methods such as the urban master plan. This is how the scheme to utilize historical properties of a region came to be completed. 